\title{
"Doshaghna Guna Ganana" (DGG) - A new arithmetic assessment of drugs' effect on dosha based on Guna prbhava (Effect of properties)
}

\section{Research article}

\section{Paramkusha Rao $\mathbf{M}^{1 *}$}

Professor \& Head, Department of DRAVYA GUNA, TTD's S. V. Ayurveda College, TIRUPATI - 517507 (A.P.), India, paramkusha@gmail.com Cell: 919393608779

\begin{abstract}
This is a first time effort to analyze the effects of drugs in a numerical way. Anything presented numerical is easily reproduced whenever and wherever is required. Drugs act by the virtue of their properties. It is called Guna Prabhava. Such effect usually influences the Doshas in the body. The action of the drug exhibited by the virtue of its nature is called Dravya Prabhava in Ayurveda. Here in this paper an effort is made to measure the Guna prabhava of Ayurveda drugs with a new method called "DOSHAGHNA GUNA GANANA" (DGG). The method is a humble effort to understand Ayurveda Pharmacology in a scientific manner.
\end{abstract}

Keywords: Dosha; Guna Ganana; Doshghnata; Dravya Prabhava; Guna Prabhava; Dravyaguna

\section{Introduction}

In Vedic literature Single drugs were just prayed and praised for their therapeutic uses. Subsequently, classification and therapeutic gradation of drugs have been dealt in Ayurveda Samhita texts. AGRAUSHADHI (Drug of choice) mentioned for many diseases is aimed at denoting the best drug or 'drug of choice' in a given indication. (1) For unknown reasons the gradation of drugs is not mentioned in NIGHANTU books. However, every Vaidya in his clinical practice is evolving his own gradation about the drugs he frequently uses. In other way the gradation helps us in

*Corresponding Author:

\section{Paramkusha Rao M,}

Professor and Head,

Dept. of Dravyaguna,

TTD's SV Ayurveda College,

Tirupati. 517507

Email id-paramkusha@gmail.com

Ph. no- 09393608779 understanding the modus operandi of the drugs a bit deeper and logical.

It is time to advance the science of DRAVYAGUNA SASTRA forward. Ayurveda herbs certainly need a definite method of gradation as several drugs are indicated in one disease and one drug is attributed with several pharmaceutical actions. Such descriptions are often reflecting vagueness. The efforts for the therapeutic gradation of drugs will provide a vertical vision and a deeper and explicate understanding of the subject. It is therefore, an effort is made in this study to grade plant drugs numerically on the basis of DOSHAGHNATA and apply it to the drugs indicated in JVARA.

The drugs' mode of action in Ayurveda:

The theory Rasapanchaka (Five Pharmacological principles of Ayurveda) is a peculiar theory and unseen in any other pharmacology. For every drug in Ayurveda five properties are explained. They are Rasa (Taste of the Drug), Guna 
(Property of the drug identified by other than tongue), Vipaka (Post Digestive inferable Taste of the drug), Virya (Potency A transient property) and Prabhava (Specific Effect).

It is usually thought these five principles will explain the mode of action of the drug. But a consistent enquiry in to these concepts reveals that first four principles out of five i.e., can explain a drugs action to a limited extent. The explanation on the basis of these four properties is cumulatively named as Guna Prabhava (Effect of Properties). The fifth principle Prabhava (Specific Effect) explains the Drugs original action. That is called as Dravya Prabhava.

\section{DRAVYANAHI DRAVYA PRABHAVAAT GUNA PRABHAVAT DRAVYA GUNA PRABHVAACCHA KAARMUKAANI BHAVANTI (2)}

Drug action in Ayurveda is explained in two stages. 1. Guna Prabhava (Virtue of Properties) and 2. Dravya Prabhava. (Virtue of the Drug proper).

Drugs act both by the virtue of GUNA (RASA, GUNA, VIPAKA and VIRYA) and also by the virtue of DRAVYA proper. Sometimes they act by the virtue of both GUNA and PRABHAVA. Therefore, it is needed to understand the influence of GUNA specified at.

DRVYAGUNA VIGNYANA has elaborately dealt with the effect and interaction of RASAPANCHAKA with the human body. Mostly the DRAVYA PRABHAVA is in tune with the GUNA PRABHAVA. The drug exhibits several actions on the virtue of their properties. However, in a given situation the DRAVYA is able to act individually and independently. This particular aspect of $D R A V Y A$ is called as PRABHAVA. Some times such effect is not explainable on the basis of RASA PANCHAKA.
Though a drug exhibits its action by the virtue of DRAVYA PRABHAVA beyond the logic of RASAPANCHAKA, still the GUNA (properties) have a usual and separate impact on the human body.

Eg. SRIGANDHA (Santalum album) causes a pleasant and cooling effect by the virtue of its DRAVYA $P R A B H A V A$. This particular action is due to its fragrance. It is its unique SVABHAVA. However SRIGANDHA (Santalum album) possessing TIKTA RASA and SITA VIRYA cause JVARAHARA, PITTAHARA and MUTRA DAHA HARA effects in the body.

\section{Guna Prabhava (Effect of Properties):}

The impact of RASA and GUNA is perceived by their effect on the DOSHA in the body. The direct influence of SADRASA on TRIDOSHA has been detailed while explaining the RASAVIKALPA in Charaka Samhita.

The RASAVIKALPA concept has less seen in later texts as it has been found that the drug acts by the virtue of GUNA, VIPAKA and VIRYA also at different times. Hence, a theory / mechanism explaining their effect on DOSHA and encompassing RASA, GUNA, VIPKA and VIRYA is to be postulated.

The ROGA HARA effect is exerted by the virtue of DRAVYA PRABHAVA proper while it may be concluded that the DOSHAGHNA effect is exerted by RASA, GUNA, VIPAKA and VIRYA. This demarcation helps us to apprehend the drug action more logically.

GUNA PRABHAVA $\rightarrow$ DOSHA KARMA

DRAVYA PRABHAVA $\rightarrow$ ROGA HARA KARMA / SAMSTAHNIKA KARMA

SAHSRENAPI HETUNAM NA AMBHASTAADIRVIRECHAYET (Susruta) (3) 
Susruta says the thousands of logics can not make the Drugs of AMBASHTADI GHANA (a group of drugs) to induce purgation. This saying hints at Dravya Prabhava. All the ingredients of the AMBASHTADI GHANA exert an action to stop diarrhea. It is the innate SVABHAVA (Nature) of the drugs possessing a particular action.

The theory of RASA PANCHAKA is evolved later to understand, manage and reproduce the activity of the drug on human body. An insight in to the physical properties of the natural drug in the terms of RASAPANCHAKA has helped us to explain the drug/food interaction with the human body. In other words RASA PANCHAKA theory is a driver software for the hardware i.e., the Drug.

\section{KINCHID DOSHA PRASAMANAM KINCHID DHATU PRADUSHANAM SVASTAVRITTAU MATAM KNCHIT TRIVIDHAM DRAVYA MUCHYATE (4)}

Drugs have been classified in to three groups in CHARAKA.

1) DOSA PRASAMANAM (Drugs Effective on Dosha)

2) DHATU PRADUSHANAM (Drugs Effective on tissues) and

3) SWASTVRITTE HITAM. (Drugs Maintain Health)

This is a premier pharmacological classification of drugs. It is to be assumed according to this classification assessment of the DOSHAGHNATA is essential to analyze a drug.

The drug's influence on DOSHA provides us an aid to select the drug. A patient of a given disease may possess different Doshic picture in a given time. Hence, it is needed to diagnose the "dosha predominance" of the patient and select an appropriate anti doshic drug in each situation. A qualified and successful Ayurveda doctor does this.
For example KANTAKARI (Solanum xanthocarpum) is anti Vata and Kapha. It is effective in VATHA KAPHA states of cough. KANTAKARI cannot effectively act on the cough caused by PITTA. In such PITTA predominant state the VASA (Adathoda vasica) which are Anti Pitta acts more effectively. DOSHAGHNATA analysis of the drug is arrived with the help of GUNA. It helps to select an apt drug based on Dosha in a given indication of a particular patient.

\section{DOSHAGHNATA (Anti Doshic Effect)}

There is one more reason to analyse the DOSHAGHNATA of the drugs. The DOSHA excited or aggravated can alone cause a disease in the human body. According to Dhyani, S.C, it is observed that majority of the diseases are caused by excited or increased aggravated state of DOSHA (5). He says increased DOSHA alone can circulate in the body to produce a disease. It is also said for the same reason:

\section{KUPITAANAM HI DOSHANAAM SARIRE PARIDHAVATAM YATRA SANGHAH KHA VAIGUNYAT VYADHI STATROPA JAYATE}

The physician need not worry for the name of the disease. If he can identify and quantify (MAANA) the excited DOSA will be able to provide treatment on the basis of DOSHGHNA principle alone. It is also said in RASA VIMANA of CHARAKA, (6) once a diagnosis is arrived based on NIDANA PANCHAKA (Five Steps of Diagnosis) it is necessary for a physician to analyse and measure the DOSHA.

Therefore it is essential for a physician to assess the DOSHA and 'Quantify' (MAANA) it in a given disease and pick up appropriate drug with corresponding DOSHAGHNA effect. DOSHAGHNATA of a drug is betokening 
to select a drug in a particular state of a disease and/or a patient. Basing on the DOSHAGHNATA one can pick up appropriate drug from number of drugs having similar ROGA HARA action.

\section{DRAVYA GUNA (Drug Properties) - Varied Effects \\ KINCHID RASENA KURUTE KARMA \\ VRYENA CHAPARAMA PARAM I \\ DRAVYAM GUNENA PAAKENA \\ PRABHAVENACHA KINCHANA // (7)}

It is clearly stated that few drugs acts some times by the virtue of RASA, few by GUNA, some other by VIRYA etc. The action of the drug is some times explained by the virtue of RASA or GUNA or VIPAKA or VIRYA. In few instances the same drug acts in given situation by the virtue of RASA and it exhibits few actions by the virtue of GUNA and so on.

For e.g. HARITHAKI (Terminalia chebula) decoction if used to wash the wound heals the wound due to RUKSHA $G U N A$. If it is given internally causes purgation by the virtue of USHANA VIRYA. If it is given to PITTA persons, it causes undesired effects hence prohibited.

Hence, it is clear that the actions performed by the virtue of GUNAs are explainable on the basis of RASA-GUNA SIDDHANTA. However it is clearly seen that the effect of RASA - GUNA are mostly focused on the DOSAS and modify their status.

Every drug has certain other actions which are not easily explainable on the basis of RASA - GUNA SIDDHANATA. $D R A V Y A$ has a specific affinity towards DUSHYA / MALA or DHATU and either increase or decrease them. The specific affinity of drugs towards a particular DATHU / AVAYAVA is its PRABHAVA.

Eg.

ARJUNA (Terminalia arjuna) $\rightarrow$
HRIDAYA (Cardiac Tonic),

KUMARI ( Aloe barbadensis) $\rightarrow$

GARBHASAYA Shodhaka (Uterine

Purifier)

Susruta also supports this view:

TAD DRAYATMANA KINCHAT

KINCHID VIRYENA SEVITAM /

KINCHIT RASA VIPAKABHYAM

DOSHAM HANTI KAROTIVA // (8)

DOSHAGHNA GUNA GANANA- A Cumulative numerical method to assess Anti Doshic effect / Guna Prbhava of the drug:

RASA / GUNA directly influence the body through DOSHA. It is easy to understand their impact on the body in the terms of DOSHAGHNA (Anti Dosha effect) effect. The cumulative Anti Dosha effect gives us an instant idea about the drug in relation to Dosha.

This has been achieved by a simple numerical method named as "DOSHAGHNA GUNA GANANA" (DGG). DGG provides a simpler way to calculate and analyze the effect of the drug on DOSHAS caused by the virtue of GUNA $P R A B H A V A$. Details are given in the tables.

\section{RASAM VIPAKASTAU VIRYAM PRABHAVASTANYAPOHATI/ \\ BALA SAMYE RASADINAM ITI NAISARGIKA BALAM // (9)}

Among RASA and other GUNAS (GUNA, VIPAKA and VIRYA) RASA is outdone by VIPAKA. It means the strength of VIPAKA would be double to RASA.

VIRYAM overtakes both RASA and VIPAKA. Hence VIRYA is Three times stronger than RASA. GUNA is not mentioned here. Therefore we may consider both RASA and GUNA have similar strength. Basing on this NAISARGIKA BALA, RASA and GUNA 
has been accorded (GANANA) "One" Numerical value in the terms of DOSHAGHNATA. For Example GURU GUNA being VATHA HARA (Pacifier of
VATHA Dosha) is accorded one numeric value as V1. The numeric values of SADRASA (Six Tastes) are shown in

Table-1: Numerical Values of DOSHAGHNATA of SADRASA

\begin{tabular}{|c|c|c|c|}
\hline $\begin{array}{l}\text { RASA } \\
\text { (Taste of the drug) }\end{array}$ & $\begin{array}{l}\text { Doshaghnata (Anti } \\
\text { Doshic Effect) }\end{array}$ & $\begin{array}{l}\text { DOSHAGHNA } \\
\text { SANKHYA } \\
\text { (Numerical Value } \\
\text { of Anti Doshic } \\
\text { Effect) }\end{array}$ & \begin{tabular}{lr}
\multicolumn{2}{l}{ CUUMULATIVE } \\
ANTI & DOSHIC \\
EFFECT & OF \\
SADRASA & (Six \\
Tastes) &
\end{tabular} \\
\hline $\begin{array}{l}\text { MADHURA } \\
\text { (SWEET) }\end{array}$ & VATHA \& PITTA & $\mathrm{V} 1, \mathrm{P} 1$ & \multirow{6}{*}{ V3, K3, P3 } \\
\hline$A M L A$ (SOUR) & VATHA & V1 & \\
\hline LAVANA (SALT) & VATA & V1 & \\
\hline TIKTA (BITTER) & PITTA \& KAPHA & $\mathrm{P} 1, \mathrm{~K} 1$ & \\
\hline KATU (PUNGENT) & KAPHA & K1 & \\
\hline $\begin{array}{l}\text { KASHAYA } \\
\text { (ASTRINGENT) }\end{array}$ & PITTA \& KAPHA & $\mathrm{K} 1, \mathrm{P} 1$ & \\
\hline
\end{tabular}

Note: The table numerically shows that the intake of SADRASA AHARA maintains the TRIDOSHA in balance.

Table-2a: DOSHA KARA GUNA - DOSHAGHNA GUNA GANANA SANKHYA (Numerical Value)

\begin{tabular}{|c|c|c|c|}
\hline DOSHA & \begin{tabular}{lcr} 
DOSA & \multicolumn{1}{c}{ KARA } & GUNA \\
(Guna & That & Aggravates \\
Dosha) & &
\end{tabular} & $\begin{array}{lr}\text { VISHESHA } & \text { GUNA- } \\
\text { (Opposite } & \text { Property } \\
\text { That Pacifies Dosha) }\end{array}$ & $\begin{array}{l}\text { DOSHAGHNA GUNA } \\
\text { GANANA SANKHYA } \\
\text { (Numerical Value of } \\
\text { Anti Doshic Effect) }\end{array}$ \\
\hline \multirow[t]{8}{*}{ VATHA } & RUKSHA (Dry) & SNIGDHA (Unctuous) & V1 \\
\hline & $L A G H U$ (Light) & GURU (Heavy) & V1 \\
\hline & SITA (Cold) & USHNA (Hot) & V1 \\
\hline & KHARA (Rough) & SLAKSHANA (Smooth) & V1 \\
\hline & SUKSHMA (Subtle) & STHULA (Gross) & V1 \\
\hline & CHALA (Mobile) & STHIRA (Stable) & V1 \\
\hline & VISHADA (Clearness) & PICCHILA (Viscid) & V1 \\
\hline & PARUSHA (Hard) & $M R I D U(\mathrm{SOFT})$ & V1 \\
\hline \multirow[t]{5}{*}{ PITTA } & USHNA (Hot) & SITA (COLD) & $\mathbf{P 1}$ \\
\hline & $\begin{array}{ll}\text { EESHAT } & S N E H A \\
\text { (Unctuous) } & \end{array}$ & ISHAT RUKSHA (Dry) & P1 \\
\hline & TIKSHANA (Sharp) & $\begin{array}{l}\text { MANDA (Dull) / } \\
M R I D U \text { (Soft) }\end{array}$ & P1 \\
\hline & $D R A V A$ (Liquid) & SANDRA (Semi Solid) & $\mathbf{P 1}$ \\
\hline & $\begin{array}{ll}\text { SARA } & \text { (Moving } \\
\text { Downwards) }\end{array}$ & STHIRA (Stable) & $\mathbf{P 1}$ \\
\hline \multirow[t]{2}{*}{ KAPHA: } & GURU (Heavy) & LAGHU (Light) & K1 \\
\hline & SITA (Cold) & USHNA (Hot) & K1 \\
\hline
\end{tabular}




\begin{tabular}{|l|l|l|l|}
\hline & SNIGDHA (Unctuous) & RUKSHA (Dry) & K1 \\
\cline { 2 - 4 } & STHIRA (Stable) & CHALA (Mobile) & K1 \\
\cline { 2 - 4 } & PICCHILA (Viscid) & VISHADA (Clearness) & K1 \\
\cline { 2 - 4 } & MRIDU (SOFT) & TIKSHANA (Sharp) & K1 \\
\hline
\end{tabular}

\section{RUKSHA SITO LAGHUH SUKSHMA CHALOATHA VISHADAH KHARAH/ VIPARITA GUNAI DRAVYAI MARUTAH SAMPRASAMYATI//}

\section{SASNEHA MUSHNAM TIKSHNAM CHA DRAVVA MAMLAM SARAM KATU/ VIPARITAGUNAIH PITTAM DRAVYAIRAASU PRASAAMYATI//}

GURU SITA MRIDU SNIGDHA MADHURA STHIRA PICCHILA/ SLESHMANAH PRASAMAMYAANTI VIPARITA GUNAIRGUNAH // (10)

The DOSHGNATA of GUNA is decided on the basis of DOSHA GUNAs said by Charaka (Charaka Sutrasthana 1/ 59 -61). The Opposite property (VISESHA GUNA) of each Guna that aggrevates dosha is accorded with one numeric value of DOSHAGHNATA. Each GUNA is accredited with one numeric value of DOSHAGHNATA as shown in Tables 2a \& $2 \mathrm{~b}$. Thus all the 20 Gunas has been accredited with one Doshaghnata numerically

Table $2 b$ : TWENTY GUNAS - GUNA DOSHAGHNA GUNA GANANA SANKHYA

\begin{tabular}{|c|c|}
\hline GUNA & DOSAGHNATA \\
\hline GURU & V1 \\
\hline$L A G H U$ & K1 \\
\hline $\bar{S} \bar{I} \bar{T} T A$ & $\mathbf{P 1}$ \\
\hline USHNA & V1K1 \\
\hline SNIGDHA & V1 \\
\hline$R U K S H A$ & K1P1 \\
\hline$M A N D A$ & P1 \\
\hline TIKSHANA & K1 V1 \\
\hline VISHADA & K1 \\
\hline PICCHILA & V1 \\
\hline SLAKSHANA & V1 \\
\hline KHARA & K1* \\
\hline SANDRA & P1 \\
\hline DRAVA & V1* \\
\hline STHIRA & V1P1 \\
\hline
\end{tabular}

\begin{tabular}{|l|l|}
\hline SARA / CHALA & $\mathbf{K 1}$ \\
\hline SUKSHMA & $\mathbf{K 1} *$ \\
\hline STHULA & $\mathbf{V 1}$ \\
\hline MRIDU & P1* \\
\hline KATHINA & $\mathbf{K 1}$ \\
\hline
\end{tabular}

Note: Few GUNAs (indicated with*) namely KHARA, DRAVA, SUKSHMA and STHULA DOSHAGHNATA is decided on the basis of their KARMA said in other texts.

VIPAKA has accorded double numeric value to that of corresponding RASA. VIRYA is denoted with Triple numerical value of corresponding GUNA. The details are shown in tables $-3 \& 4$.

Tables - 3: VIPAKA DOSHAGHNATA

\begin{tabular}{|l|l|}
\hline VIPAKA & $\begin{array}{l}\text { DOSHAGHNATA } \\
\text { (Double to RASA) } \\
\text { MADHURA }\end{array}$ \\
V2P2 \\
AMLA & V2 \\
KATU & K2 \\
\hline
\end{tabular}


Tables - 4: VIRYA DOSHAGHNATA

\begin{tabular}{|l|l|}
\hline VIRYA & $\begin{array}{l}\text { DOSHAGHNATA } \\
\text { (Triple to GUNA) } \\
\text { USHNA }\end{array}$ \\
VIT K3 \\
PITA & P3 \\
ANUSHANA* & V1 P1 K1 \\
\hline
\end{tabular}

*Drugs like Saindhava are said to possess Aushna Virya. This third variety of Virya is seen in Nighantus.

Sum total of the numerical values of RASA, GUNA, VIPAKA and VIRYA is considered as the Cumulative DOSHAGHNATA of the drug. This numerical effort is providing a clearer and unique insight on the DOSHAGHNATA of each drug. It has dispelled the vagueness in understanding the impact of RASA PANCHAKA at once.

\section{DOSHAKARA PRABHAVA - Selection of drug}

The Rasa's promotion effect on DOSHA should also be considered in a given disease. Though a drug having similar SAMSTHANIKA KARMA may promote or increase a DOSHA present in the pathogenesis by virtue of its RASA and GUNA. Such drug is considered as counter effective.

E.g. For example ARJUNA

(Terminalia arjuna Roxb.) and Pushkaramula ( Innula recemosa Hook.F) are two drugs indicated in Heart diseases. Pushkaramula (Innula recemosa Hook.F) is anti Vata and Kapha. It is effective in VATHA KAPHA states \& types of Heart disease. Pushkaramula (Innula recemosa Hook.F) cannot effectively act on the
Heart disease caused by PITTA. In such PITTA predominant state the ARJUNA (Terminalia arjuna Roxb.) which is being Anti Pitta acts more effectively. Therefore the best drug in PITTAJA HRIDROGA (Heart Disease) would be ARJUNA. Similarly PUSKARAMULA (Innula recemosa Hook.F) would be best drug in HRIDROGA (Heart Disease) caused by predominant VATA \& KAPHA DOSHA. This is how the selection of drug is to be made in Ayurveda.

\section{ROGA BHEDA - DOSHA}

All diseases in SAMHITA texts are simply classified on the basis of DOSHA. This is done to be selective in the treatment. In fact one has to assess the DOSHA and proceed for treatment. In other words the diagnosis by an Ayurveda physician is nothing but DOSHA analysis of the disease. E.g. VATHA JVARA, PITTAJA JVARA etc.

\section{JVARA HARA DRAVYA - DOSHGNA GUNA GANANA}

Drugs mentioned effective in JVARA by CARAKA \& VAGBHATA are selected to examine the DOSHAGHNA GUNAGANANA (DGG) method. DOSHAGHNATA of certain JVARAHARA drugs is graded in to categories on the basis of their GUNAS connoted in Bhavaprakasha Nighantu. A numerical gradation of cumulative Doshic effect is evolved with the help of "DOSHAGHNAGUNA GANANA" procedure. The details are presented in the table -5 and 6 . 
Table - 5:

JVARAHARA DRAVYA (Anti Pyretic Drugs) Mentioned in Texts of Ayurveda

\begin{tabular}{|l|l|l|}
\hline \multicolumn{1}{|c|}{ Sanskrit Name } & & \multicolumn{1}{|c|}{ Botanical Name } \\
\hline 1. LATAKARANJA & $:$ & Caesalpinia bonduc (L) Roxb. \\
\hline 2. DARUHARIDRA & $:$ & Bereberis aristata DC \\
\hline 3. PATOLA & $:$ & Trichosanthes dioica Roxb. \\
\hline 4. TRAYAMANA & $:$ & Gentiana kurroa Royle. \\
\hline 5. VATSANABHI & $:$ & Aconitum ferox Wall. \\
\hline 6. MUSTAKAM & $:$ & Cyperus rotundus Linn. \\
\hline 7. ASWA KARNA & $:$ & Dipterocarpus turbinatus Gaertn. \\
\hline 8. PARIBADRA & $:$ & Erythrina indica Lamk. \\
\hline 9. SAHADEVI & $:$ & Veronia cinerea \\
\hline 10. DRONA PUSPI & $:$ & Leucas cephalotus Spring. \\
\hline 11. KIRATA TIKTA & $:$ & Swertia chirata Buch. Ham. \\
\hline 12. PARPATAKA & $:$ & Fumaria parviflora Lam. \\
\hline 13. KALAMEGHA & $:$ & Andrographis paniculata (Burm. F.) Wall. Ex Nees \\
\hline 14. KAKAMACHI & $:$ & Solanam nigrum Linn. \\
\hline
\end{tabular}

Table - 6:

JVARAHARA DRAVYA (Anti Pyretic Drugs) Mentioned in Texts of Ayurveda DOSHAGHNA GUNA GANANA Calculated on the DOSHGHNATA Values Given to RASA, GUNA, VIPAKA \& VIRYA As Mentioned in Table No. 1 to Table No. 5

\begin{tabular}{|l|l|l|l|l|l|}
\hline \multirow{2}{*}{ DRAVYA } & RASA & GUNA & VIPAKA & VIRYA & $\begin{array}{l}\text { CUMULAT } \\
\text { IVE } \\
\text { SANKHYA }\end{array}$ \\
\hline 1. LATAKARANJA & $\begin{array}{l}\text { TIKTA, } \\
\text { KASHAYA }\end{array}$ & $\begin{array}{l}\text { LAGHU, } \\
\text { RUKSHA }\end{array}$ & KATU & USHNA & K9,P3, V3 \\
& $\begin{array}{l}\text { P1 K1, K1 } \\
\text { P1+ }\end{array}$ & K1, K1 P1+ & K2+ & V3 K3= & \\
\hline 2. DARUHARIDRA & $\begin{array}{l}\text { TIKTA, } \\
\text { KASHAYA }\end{array}$ & $\begin{array}{l}\text { LAGHU, } \\
\text { RUKSHA }\end{array}$ & KATU & USHNA & K9,P3, V3 \\
\hline
\end{tabular}




\begin{tabular}{|c|c|c|c|c|c|}
\hline & $\begin{array}{l}\text { P1 K1, K1 } \\
\text { P1+ }\end{array}$ & K1, K1 P1+ & $K 2+$ & $V 3 K 3=$ & \multirow{3}{*}{$K 9, V 3, P 2$} \\
\hline \multirow[t]{2}{*}{ 3. PATOLA } & $\begin{array}{l}\text { TIKTA, } \\
\text { KATU }\end{array}$ & $\begin{array}{l}L A G H U, \\
R U K S H A\end{array}$ & $K A T U$ & USHNA & \\
\hline & $\begin{array}{l}P 1 \quad K 1, \\
K 1+\end{array}$ & K1, K1 P1+ & $K 2+$ & $V 3 K 3=$ & \\
\hline \multirow[t]{2}{*}{ 4. TRAYAMANA } & $\begin{array}{l}\text { TIKTA; } \\
\text { KASHAYA }\end{array}$ & $\begin{array}{l}L A G H U ; \\
R U K S H A\end{array}$ & $K A T U$ & USHNA & \multirow[t]{2}{*}{ K9, V3, P3 } \\
\hline & $\begin{array}{l}P 1 \mathrm{~K} 1 ; \mathrm{K} 1 \\
P 1+\end{array}$ & $K 1 ; K 1 P 1+$ & $K 2+$ & $V 3 K 3=$ & \\
\hline \multirow[t]{2}{*}{ 5. VATSANABHI } & $\begin{array}{l}\text { MADHUR } \\
A\end{array}$ & $\begin{array}{l}\text { LAGHU, } \\
\text { RUKSHA, } \\
\text { TIKSHNA, } \\
\text { VYAVAYI }\end{array}$ & $K A T U$ & USHNA & \multirow[t]{2}{*}{$K 8, V 5, P 2$} \\
\hline & V1 P1+ & $\begin{array}{l}K 1, \quad K 1 \\
K 1 V 1,0+\end{array}$ & $K 2+$ & $V 3 K 3=$ & \\
\hline \multirow[t]{2}{*}{ 6. MUSTAKAM } & $\begin{array}{l}\text { TIKTA, } \\
\text { KATU, } \\
\text { KASHAYA }\end{array}$ & $\begin{array}{l}L A G H U, \\
R U K S H A\end{array}$ & $K A T U$ & SITA & \multirow[t]{2}{*}{ K7,P6 } \\
\hline & $\begin{array}{l}P 1 \mathrm{~K} 1, \mathrm{~K} 1, \\
\text { K1 P1+ }\end{array}$ & K1, K1 P1+ & $K 2+$ & $P 3=$ & \\
\hline \multirow[t]{2}{*}{ 7. ASWA KARNA } & $\begin{array}{l}\text { KATU, } \\
\text { TIKTA }\end{array}$ & $\begin{array}{l}\text { LAGHU; } \\
\text { SNIGDHA }\end{array}$ & $K A T U$ & USHNA & \multirow[t]{2}{*}{$K 9, V 4, P 1$} \\
\hline & $\begin{array}{l}K 1, \quad P 1 \\
K 1+\end{array}$ & $K 1 ; V 1+$ & $K 2+$ & V3 K3= & \\
\hline \multirow[t]{2}{*}{ 8. PARIBADRA } & $\begin{array}{l}\text { KATU, } \\
\text { TIKTA }\end{array}$ & $L A G H U$ & $K A T U$ & USHNA & \multirow[t]{2}{*}{$K 8, V 3, P 1$} \\
\hline & $\begin{array}{l}K 1, \quad P 1 \\
K 1+\end{array}$ & $K 1+$ & $K 2+$ & $V 3 K 3=$ & \\
\hline \multirow[t]{2}{*}{ 9. SAHADEVI } & TIKTA & $\begin{array}{l}L A G H U ; \\
R U K S H A\end{array}$ & $K A T U$ & USHNA & \multirow[t]{2}{*}{$K 8, V 3, P 2$} \\
\hline & P1 K1+ & K1; K1 P1+ & $K 2+$ & $V 3 K 3=$ & \\
\hline \multirow[t]{2}{*}{ 10. DRONA PUSPI } & $K A T U$ & $\begin{array}{l}\text { GURU, } \\
R U K S H A\end{array}$ & $K A T U$ & USHNA & \multirow[t]{2}{*}{$K 7, V 4, P 1$} \\
\hline & $K 1+$ & $V 1, K 1 P 1+$ & $K 2+$ & $V 3 K 3=$ & \\
\hline \multirow[t]{2}{*}{ 11. KIRATA TIKTA } & $T I K T A$ & $\begin{array}{l}L A G H U, \\
R U K S H A\end{array}$ & $K A T U$ & SITA & \multirow[t]{2}{*}{ K5,P5 } \\
\hline & P1 K1+ & K1, K1 P1 + & $K 2+$ & $P 3=$ & \\
\hline \multirow[t]{2}{*}{ 12. PARPATAKA } & TIKTA & $L A G H U$ & $K A T U$ & SITA & \multirow[t]{2}{*}{$K 5, P 4$} \\
\hline & P1 K1+ & $K 1+$ & $K 2+$ & $P 3=$ & \\
\hline \multirow[t]{2}{*}{ 13. KALAMEGHA } & TIKTA & $\begin{array}{l}L A G H U ; \\
R U K S H A\end{array}$ & $K A T U$ & $\begin{array}{l}\text { ANUSHN } \\
\text { A }\end{array}$ & \multirow[t]{2}{*}{$K 6, P 3, V 1$} \\
\hline & $P 1 K 1$ & K1; K1 P1 & $K 2+$ & $\begin{array}{l}V 1 \\
P 1=\end{array}$ & \\
\hline \multirow[t]{2}{*}{ 14. КАКАМАСНI } & TIKTA & $\begin{array}{l}\text { LAGHU; } \\
\text { SNIGDHA }\end{array}$ & $K A T U$ & $\begin{array}{l}\text { ANUSHN } \\
\text { A }\end{array}$ & \multirow[t]{2}{*}{$K 5, V 3, P 2$} \\
\hline & P1 K1+ & $K 1 ; V 1+$ & $K 2+$ & $\begin{array}{c}V 1 \\
P 1=\end{array}$ & \\
\hline
\end{tabular}




\section{Conclusion:}

The study shows that all the drugs can be comfortably graded in to various categories basing on their intensity of DOSHAGHNATA. The grading method gives us an instant picture of the drug with reference to DOSHA. The physician can be very selective in selecting a drug apt for the given situation in a patient of JVARA or for that matter in any disease. However, the purpose of grading the drugs is fruitful only when the physician assesses the level of DOSHA in the body. The quantification of DOSHA in the patient is the need of the hour to succeed and explore newer treatments.

This method can also be applied to the ingredients of a drug and estimate the cumulative anti doshic effect of the compound. Further studies can be planned in this direction

\section{References:}

1. Agnivesha, Caraka Samhita, Elaborated Vidyothini Hindi Comentary by Pt. Kasinatha Sastry \& Gorakhnath Chaturvedi, Chowkamba Bharathi Academy, Varanasi, $11^{\text {th }}$ edition, 1983. Vol.1 Sutra Sthana. 30th chapter. PP 581

2. Agnivesha, Caraka Samhita, Elaborated Vidyothini Hindi Comentary by Pt. Kasinatha Sastry \& Gorakhnath Chaturvedi, Chowkamba Bharathi Academy, Varanasi, $11^{\text {th }}$ edition, 1983. Vol.1 Sutra Sthana. 30th chapter, PP 468.

3. Susrutha, Susrutha Samhita (Tet with English Translation \& Critical Exposition Based on Cakrapani Datta's Ayurveda Dipika by Sharma R.K., \& Bhagavan Das, Chawkamba Vishvabharathi, Oriental Publishers, Varanasi, Reprint 2005. Vol.1 Sutra Sthana. Chapter 40,

4. Agnivesha, Caraka Samhita,
Elaborated Vidyothini Hindi Comentary by Pt. Kasinatha Sastry \& Gorakhnath Chaturvedi, Chowkamba Bharathi Academy, Varanasi, $11^{\text {th }}$ edition, 1983. Vol.1 Sutra Sthana. $1^{\text {st }}$ chapter, Verse 68, PP 40

5. Dhyani, S.C. - Nidana Panchaka, Hindi Book, Chowkamba Surabharati Publications, Varanasi, First Edition 1987., PP 15

6. Agnivesha, Caraka Samhita, Elaborated Vidyothini Hindi Comentary by Pt. Kasinatha Sastry \& Gorakhnath Chaturvedi, Chowkamba Bharathi Academy, Varanasi, $11^{\text {th }}$ edition, 1983. Vol.1, Vimana Sthana. $1^{\text {st }}$ chapter. Verse 3, PP 670

7. Agnivesha, Caraka Samhita, Elaborated Vidyothini Hindi Comentary by Pt. Kasinatha Sastry \& Gorakhnath Chaturvedi, Chowkamba Bharathi Academy, Varanasi, $11^{\text {th }}$ edition, 1983. Vol.1 Sutra Sthana, 26 ${ }^{\text {th }}$ chapter, Verse 71/72, PP 515

8. Susrutha, Susrutha Samhita, English Translation of text and Dalhana's commentary along with critical notes, by $\mathrm{P}$ V Sharma, Chawkamba Vishvabharathi, Oriental Publishers, Varanasi, Reprint 2005. Vol.1 Sutra Sthana. $40^{\text {th }}$ Chapter, PP 373

9. Agnivesha, Caraka Samhita, Elaborated Vidyothini Hindi Comentary by Pt. Kasinatha Sastry \& Gorakhnath Chaturvedi, Chowkamba Bharathi Academy, Varanasi, $11^{\text {th }}$ edition, 1983. Vol.1 Sutra Sthana, 26 ${ }^{\text {th }}$ chapter, Verse 72/73, PP 516

10. Agnivesha, Caraka Samhita, Elaborated Vidyothini Hindi Comentary by Pt. Kasinatha Sastry \& Gorakhnath Chaturvedi, Chowkamba Bharathi Academy, Varanasi, $11^{\text {th }}$ edition, 1983. Vol.1 Sutra Sthana, $1^{\text {st }}$ chapter, Verse 59-61, PP 36 \& 37 